medRxiv preprint doi: https://doi.org/10.1101/2020.09.10.20179135; this version posted September 11 , 2020. The copyright holder for this preprint (which was not certified by peer review) is the author/funder, who has granted medRxiv a license to display the preprint in It is made available under a CC-BY-NC-ND 4.0 International license .

\title{
The influence of pH on SARS-CoV-2 infection and COVID-19 severity
}

\section{Authors:}

Leandro Jimenez ${ }^{1,2}$, Ana Campos Codo ${ }^{3}$, Vanderson de Souza Sampaio ${ }^{4,5,6,7}$, Antonio E.R. Oliveira$^{1}$, Lucas Kaoru Kobo Ferreira¹, Gustavo Gastão Davanzo³ ${ }^{3}$, Lauar de Brito Monteiro³, João Victor Virgilio-da-Silva ${ }^{3}$, Mayla Gabriela Silva Borba ${ }^{4}$, Gabriela Fabiano de Souza ${ }^{3}$, Nathalia Zini ${ }^{8}$, Flora de Andrade Gandolfi ${ }^{8}$, Stéfanie Primon Murano ${ }^{3}$, José Luiz ProençaModena $^{3}$, Fernando Almeida Val',5,7, Gisely Cardoso Melo ${ }^{4,5}$, Wuelton Marcelo Monteiro ${ }^{4,5}$, Maurício Lacerda Nogueira ${ }^{8}$, Marcus Vinícius Guimarães Lacerda ${ }^{4,5,9}$, Pedro M. MoraesVieira $^{3,10,11}$, Helder I Nakaya ${ }^{1,2,{ }^{*}}$

\section{Affiliations:}

${ }^{1}$ Department of Clinical and Toxicological Analyses, School of Pharmaceutical Sciences, University of São Paulo, São Paulo, Brazil.

2 Scientific Platform Pasteur-University of São Paulo, São Paulo, Brazil.

${ }^{3}$ Department of Genetics, Evolution, Microbiology and Immunology, Institute of Biology, University of Campinas, SP, Brazil.

${ }^{4}$ Fundação de Medicina Tropical Dr Heitor Vieira Dourado, Manaus, Brazil

${ }^{5}$ Universidade do Estado do Amazonas, Manaus, Brazil

${ }^{6}$ Fundação de Vigilância em Saúde do Amazonas, Manaus, Brazil

7 Faculdade de Medicina da Universidade Federal do Amazonas, Manaus, Brazil, UFAM Amazonas, Manaus, Brazil

${ }^{8}$ Faculdade de Medicina de São José do Rio Preto, São Paulo, Brazil

${ }^{9}$ Faculdade de Medicina da Universidade Federal do Amazonas, Manaus, Brazil, UFAM Amazonas, Manaus, Brazil

10 Obesity and Comorbidities Research Center (OCRC), University of Campinas, SP, Brazil.

${ }^{11}$ Experimental Medicine Research Cluster (EMRC), University of Campinas, SP, Brazil.

*Correspondence to: hnakaya@usp.br 
medRxiv preprint doi: https://doi.org/10.1101/2020.09.10.20179135; this version posted September $11,2020$. The copyright holder for this preprint (which was not certified by peer review) is the author/funder, who has granted medRxiv a license to display the preprint in It is made available under a CC-BY-NC-ND 4.0 International license .

\section{Abstract}

The severe acute respiratory syndrome coronavirus 2 (SARS-CoV-2) can infect a broad range of human tissues by using the host receptor angiotensin-converting enzyme 2 (ACE2). Individuals with comorbidities associated with severe COVID-19 display higher levels of ACE2 in the lungs compared to those without comorbidities, and conditions such as cell stress, elevated glucose levels and hypoxia may also increase the expression of $A C E 2$. Here we showed that patients with Barrett's esophagus (BE) have a higher expression of ACE2 in $\mathrm{BE}$ tissues compared to normal squamous esophagus, and that the lower $\mathrm{pH}$ associated with $\mathrm{BE}$ may drive this increase in expression. Human primary monocytes cultured in reduced $\mathrm{pH}$ displayed increased ACE2 expression and viral load upon SARS-CoV-2 infection. We also showed in two independent cohorts of COVID-19 patients that previous use of proton pump inhibitors is associated with 2- to 3-fold higher risk of death compared to those not using the drugs. Our work suggests that $\mathrm{pH}$ has a great influence on SARS-CoV-2 Infection and COVID-19 severity.

\section{Keywords}

COVID-19; pH; SARS-CoV-2; proton pump inhibitors; Barrett's esophagus. 
medRxiv preprint doi: https://doi.org/10.1101/2020.09.10.20179135; this version posted September 11, 2020. The copyright holder for this preprint (which was not certified by peer review) is the author/funder, who has granted medRxiv a license to display the preprint in It is made available under a CC-BY-NC-ND 4.0 International license.

\section{Introduction}

As of August 2020, the severe acute respiratory syndrome coronavirus 2 (SARS-CoV2) infected over 20 million people worldwide (World Health Organization). The new coronavirus disease 2019 (COVID-19) caused by SARS-CoV-2 is characterized by a broad range of symptoms, from respiratory to neurological and digestive problems (1, 2). Although a small fraction of patients develop highly lethal pneumonia, at least $20 \%$ of COVID-19 patients may display one or more gastrointestinal (Gl) symptoms (1), such as diarrhea, vomiting, and abdominal pain $(2,3)$.

SARS-CoV-2 tissue tropism can be directly linked to the diverse clinical manifestations of COVID-19. The receptor used by the virus to enter the cells is the angiotensin-converting enzyme 2 (ACE2), which is found in several tissues, including the Gl epithelial cells and liver cells $(4,5)$. SARS-CoV-2 was detected in biopsies of several tissues, including esophagus, stomach, duodenum and rectum, and endoscopy of hospitalized patients revealed esophageal bleeding with erosions and ulcers $(2,6)$.

Higher levels of ACE2 in the tissues may explain in part some of the comorbidities associated with severe COVID-19. Recently, we showed that ACE2 was highly expressed in the lungs of people with pulmonary arterial hypertension and chronic obstructive diseases (7). Since the expression of ACE2 changes under conditions of cell stress, elevated glucose levels and hypoxia $(8,9)$, other comorbidities related to the $\mathrm{Gl}$ tract can be associated with different forms of COVID-19.

Here we suggest that gastroesophageal reflux disease (GERD) and Barrett's esophagus (BE) may represent novel comorbidities associated with COVID-19. In the United States, it has been estimated that $5.6 \%$ of adults have BE, a disease where GERD damages the esophageal squamous mucosa (10). Here we demonstrated that ACE2 is highly expressed in the esophagus of patients with $\mathrm{BE}$ and that the acid $\mathrm{pH}$ associated with this condition is a key inducer of ACE2 expression. Human primary monocytes cultured in reduced pH display increased expression of ACE2 and increased viral load upon SARS-CoV2 infection. We also show that patients using proton pump inhibitors, which are recommended for GERD treatment, have a higher risk of developing severe COVID-19, observed by an increased risk of ICU admittance and death. 
medRxiv preprint doi: https://doi.org/10.1101/2020.09.10.20179135; this version posted September $11,2020$. The copyright holder for this preprint (which was not certified by peer review) is the author/funder, who has granted medRxiv a license to display the preprint in It is made available under a CC-BY-NC-ND 4.0 International license .

\section{Methods}

\section{Acidosis and Barrett's esophagus meta-analysis}

We manually curated the Gene Expression Omnibus (GEO) repository (https://www.ncbi.nlm.nih.gov/geo/) to find esophagus transcriptome datasets related to "Barrett's esophagus" and cell line transcriptome datasets related to "acidosis" and "pH reduction". Author-normalized expression values and metadata from these datasets were downloaded using the GEOquery package (11). We performed differential expression analyses using the limma package (12). The GEO study ID and the groups of samples compared are listed in Supplementary Table 1. The MetaVolcanoR package (13) was used to combine the $P$ values using the Fisher's method. To adjust for multiple comparisons, we calculated the false discovery rate (FDR) using the Benjamini-Hochberg procedure. For enrichment analyses, we utilized the EnrichR tool (14) and fgsea R package (15) with gene sets from the Gene Ontology Biological Process database. We then selected pathways with a $P$ value adjusted for multiple comparisons lower than 0.10 .

\section{Single cell transcriptomic analysis of Barrett's esophagus}

The single cell RNA-seq (scRNA-seq) data from esophagus, Barrett's esophagus, gastric and duodenum cells from patients with BE were acquired from Owen et al. 2018 (16). Cells with less than 1,000 genes were excluded from analysis using Seurat v3 (17). Raw UMI counts were log transformed and variable genes called on each dataset independently based on the VST method. The AddModuleScore function was used to remove batch effects between samples and based on C1orf43, CHMP2A, EMC7, GPI, PSMB2, PSMB4, RAB7A, REEP5, $S N R P D 3, V C P, V P S 29$ genes. We assigned scores for $S$ and G2/M cell cycle phases based on previously defined gene sets using the CellCycleScoring function. Scaled z-scores for each gene were calculated using the ScaleData function and regressed against the number of UMls per cell, mitochondrial RNA content, $S$ phase score, G2/M phase score, and housekeeping score. Scaled data was used as an input into PCA based on variable genes. These PCA components were used to generate the UMAP reduction visualization. To identify the number of clusters, UMI log counts were used as input to SC3 (18). Technical variation was tested using BEARscc (19), which models technical noise from ERCC spike-in measurements. The clusters were then annotated based on genes previously characterized (16). 
medRxiv preprint doi: https://doi.org/10.1101/2020.09.10.20179135; this version posted September $11,2020$. The copyright holder for this preprint (which was not certified by peer review) is the author/funder, who has granted medRxiv a license to display the preprint in

It is made available under a CC-BY-NC-ND 4.0 International license .

\section{Peripheral blood mononuclear cells (PBMC) isolation}

Buffy coats provided by the Hematology and Hemotherapy Center of the University of Campinas (SP-Campinas, Brazil) were used for PBMC isolation as described (9). The study was approved by the Brazilian Committee for Ethics in Human Studies (CAAE: 31622420.0.0000.5404). Briefly, buffy coats were mixed and then diluted in Phosphate Buffer

Saline (PBS) (1:1) and carefully to $50 \mathrm{~mL}$ tube containing Ficoll (Sigma-Aldrich) and centrifuged. PBMCs were cultured in RPMI 1640 for 2-3h to allow cell adhesion. Next, cells were washed twice with PBS and adherent cells, enriched in monocytes, were further incubated until infection in RPMI 1640 containing 10\% fetal bovine serum (FBS) and 1\% Penicillin-Streptomycin (Pen-Strep) at $37^{\circ} \mathrm{C}$ with $5 \%$ CO2. Monocytes were maintained in different $\mathrm{pH}$ levels $(6,6.5$, and 7.4$)$ during $24 \mathrm{~h}$ and subsequently infected with SARS-CoV-2, as described below.

\section{Viruses and infection}

HIAE-02 SARS-CoV-2/SP02/human/2020/BRA (GenBank MT126808.1) virus was isolated as described (9). Stocks of Sars-CoV-2 were prepared in the Vero cell line. The supernatant was harvested at 2-3 dpi. Viral titers were obtained by plaque assays on Vero cells. Monocytes were infected with SARS-CoV-2 at MOI 0.1 under continuous agitation at $15 \mathrm{rpm}$ for $1 \mathrm{~h}$. Next, monocytes were washed twice and incubated in RPMI with 10\% FBS and 1\% Pen-Strep for $24 \mathrm{~h}$ at $37^{\circ} \mathrm{C}$ with $5 \% \mathrm{CO} 2$ for 24 hours.

\section{Viral load and gene expression analyses}

Total RNA extraction was performed using TRlzol Reagent (Sigma-Aldrich). RNA concentration was measured with NanoDrop 2000 spectrophotometer (Thermo Scientific). RNA was reverse-transcribed using GoScript ${ }^{\mathrm{TM}}$ Reverse Transcriptase cDNA synthesis kit following manufacturer's instructions. SARS-CoV-2 viral load was determined with primers targeting the $\mathrm{N} 1$ region and a standard curve was generated as described (20). Viral load and gene expression were made using SYBR Green Supermix in BIO-RAD CFX394 Touch Real-Time PCR Detection System. Fold change was calculated as $2^{\wedge}-\Delta \triangle C$ t. Primer sequences used: 18S (Forward: 5'-CCCAACTTCTTAGAGGGACAAG-3'; Reverse: 5'CATCTAAGGGCATCACAGACC-3'); ACE2 (Forward: 5'-GGACCCAGGAAATGTTCAGA-3'; Reverse: 5'-GGCTGCAGAAAGTGACATGA-3'); SARS-CoV-2_IBS_N1 (Forward: 5'CAATGCTGCAATCGTGCTAC-3'; Reverse: 5'-GTTGCGACTACGTGATGAGG-3'). 
medRxiv preprint doi: https://doi.org/10.1101/2020.09.10.20179135; this version posted September 11,2020 . The copyright holder for this preprint (which was not certified by peer review) is the author/funder, who has granted medRxiv a license to display the preprint in It is made available under a CC-BY-NC-ND 4.0 International license .

\section{Clinical data analysis}

We retrieved clinical data from two independent cohorts of 551 and 806 RT-qPCR confirmed COVID-19 patients aged 18 years or older that went to reference hospitals for COVID-19 in Manaus, Amazonas, Brazil (North region cohort) and in São José do Rio Preto city, São Paulo, Brazil (Southeast region cohort), respectively. They were followed for at least 28 days (North region cohort) or 120 days (Southeast region cohort) after recruitment. Information about the previous history of proton pump inhibitors use (e.g. omeprazole and pantoprazole), a surrogate evidence of low gastric $\mathrm{pH}$-related diseases, time of hospitalization, ICU admittance, and time to death, as well as demographics, previous use of other drugs, clinical, laboratory, and outcome variables were collected. The protocol was approved by the Brazilian Committee of Ethics in Human Research (CAAE: 30152620.1.0000.0005 and 30615920.2.0000.0005 for North region cohort, and 31588920.0.0000.5415 for Southeast region cohort). Data were collected and managed using REDCap (v. 10.2.1) electronic data capture tools hosted at Fundação de Medicina Tropical Dr. Heitor Vieira Dourado.

Adjusted hazard ratios and risk ratios with respective 95\% confidence intervals $(\mathrm{Cl})$ were estimated for time to death and ICU admittance, respectively by Cox regression and log-binomial generalized linear model models. To adjust for confounders, ages higher than 60 years old and obesity, defined by both BMI and fat percentage, were used as covariables in the multivariable analyses. Wilcoxon Rank-Sum analysis was used to test differences in the days of hospitalization. A 2-tailed $P<0.05$ was considered significant. The statistical analyses were carried out using Stata v. 13.0 (StataCorp LP, College Station, TX).

\section{Results}

To evaluate whether people with BE may have higher chances of being infected with SARS-CoV-2 when compared to people without the disease, we performed a meta-analysis of 8 transcriptomic studies of BE (Figure 1A, Table S1). A total of 304 and 256 genes displayed, respectively higher and lower expression $\mathrm{BE}$ compared to normal esophagus tissue in at least 7 of these studies (Figure 1B). ACE2 was among the genes consistently upregulated in the BE compared to normal esophagus (Figure 1C). While pathways related to keratinocyte differentiation and epidermis development were enriched with down-regulated genes, we found that bicarbonate transport and regulation of intracellular $\mathrm{pH}$ pathways were enriched with up-regulated genes (Figure 1D), suggesting that $\mathrm{pH}$ may influence ACE2 expression. In fact, when human coronary artery endothelial cells were treated with proton 
medRxiv preprint doi: https://doi.org/10.1101/2020.09.10.20179135; this version posted September 11, 2020. The copyright holder for this preprint (which was not certified by peer review) is the author/funder, who has granted medRxiv a license to display the preprint in

pump inhibitors - omeprazole or lansoprazole - the expression of ACE2 decreased in comparison to untreated cells (Figure 1E). Gene set enrichment analysis (GSEA) confirmed that Barrett's esophagus tissues have higher expression of genes related to $\mathrm{pH}$ alterations (Figure 1F).

A

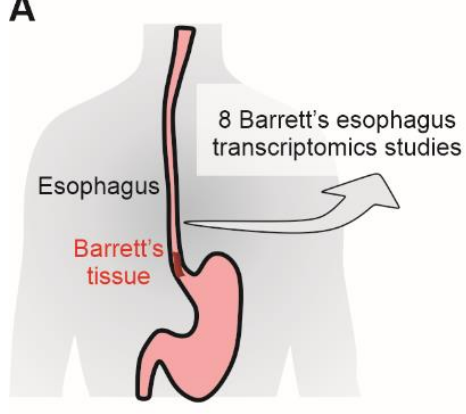

D

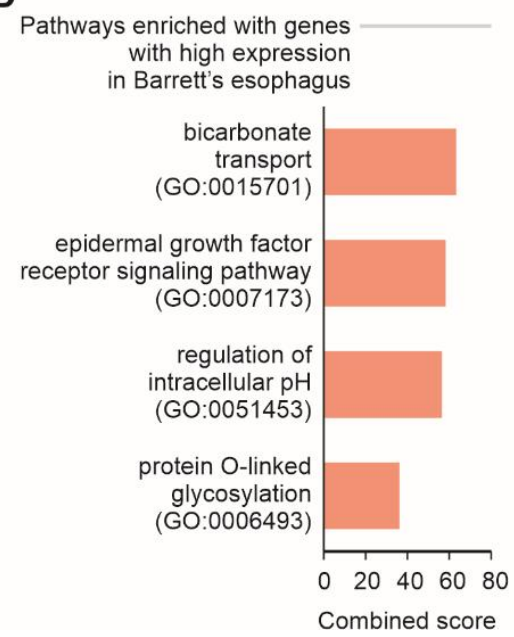

B

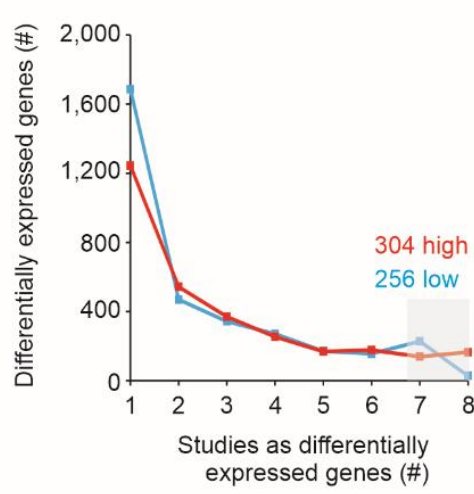

E

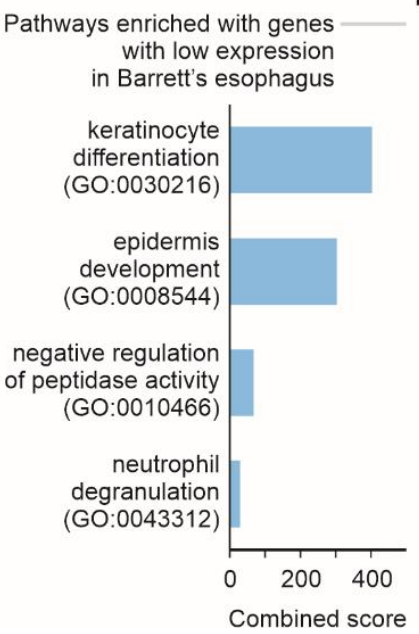

C
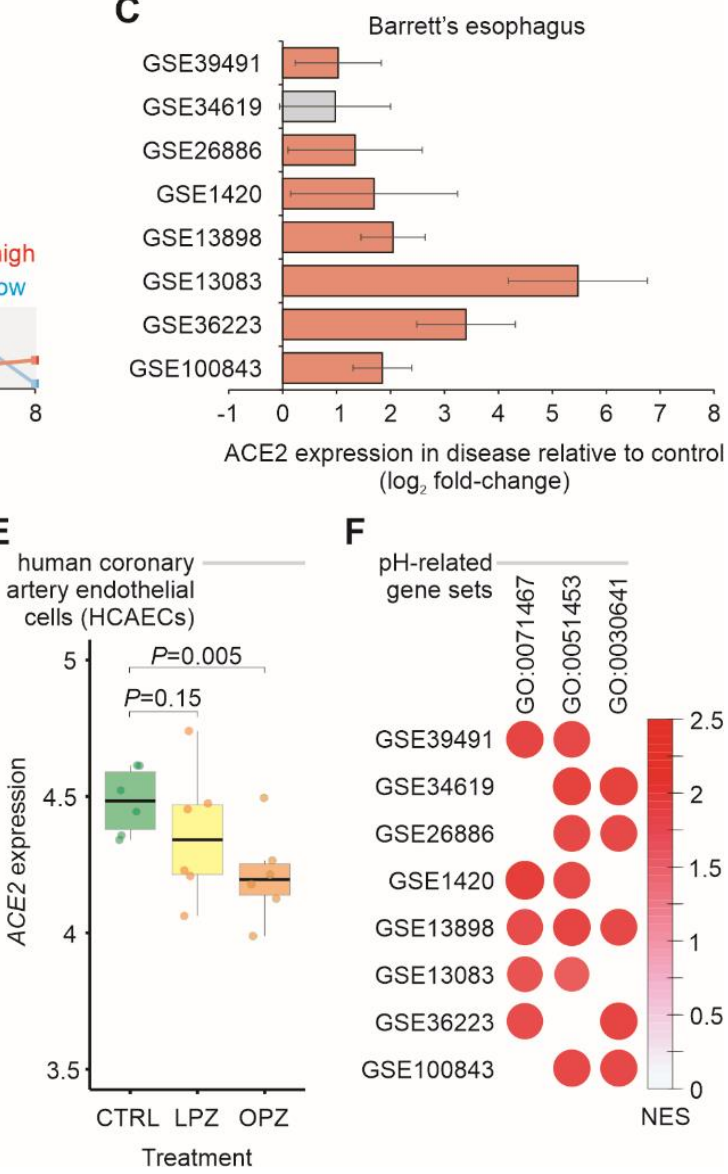

$\mathbf{F}$

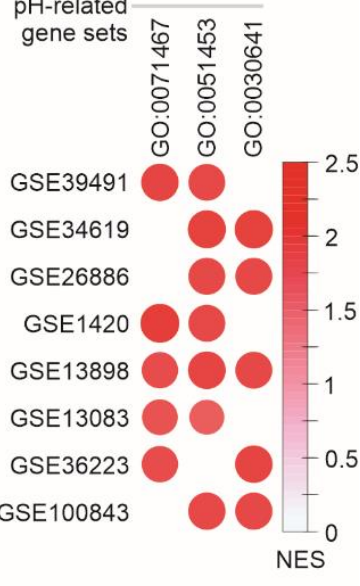

Figure 1. Meta-analysis of gastroesophageal junction transcriptomes of patients with

Barrett's esophagus. A. Meta-analysis of 8 studies of Barrett's esophagus transcriptomes.

B. Number of differentially expressed genes in Barrett's esophagus compared with nonBarrett's esophagus. The lines show the number of genes ( $y$-axis) considered up-regulated (red lines) or down-regulated (blue lines) in Barrett's esophagus ( $P$ value < 0.05; log2 foldchange $>1$; combined FDR < 0.01) in one or more datasets ( $x$-axis). The numbers of upregulated and down-regulated genes in at least 7 studies are indicated. C. ACE2 is upregulated in patients with Barrett's esophagus. Each bar represents the log2 expression fold-change between patients and control individuals. The error bars indicate the $95 \%$ confidence interval. Bars in red represent a $P$ value $<0.05$ and in grey a non-significant $P$ value. D. Pathway enrichment analysis using the up-regulated and down-regulated genes in at least 7 studies. The bars represent the combined score (x axis) calculated by Enrichr tool 
medRxiv preprint doi: https://doi.org/10.1101/2020.09.10.20179135; this version posted September 11, 2020. The copyright holder for this preprint (which was not certified by peer review) is the author/funder, who has granted medRxiv a license to display the preprint in It is made available under a CC-BY-NC-ND 4.0 International license.

for selected Gene Ontology gene sets (y axis). E. ACE2 expression in cells treated with proton pump inhibitors. Each boxplot represents the log2 expression of untreated (CTRL) cells and cells treated with either omeprazole (OPZ) or lansoprazole (LPZ). F. Gene Set Enrichment Analysis (GSEA) of the 8 studies of Barrett's esophagus transcriptomes using $\mathrm{pH}$-related gene sets. The size and color of the circles are proportional to the normalized enrichment score (NES) of the gene sets (columns) on each study (rows). The Gene Ontology IDs are indicated at the top.

We also investigated ACE2 expression in Barrett's esophagus at single-cell level. Our analysis showed that single cells from Barrett's esophagus patients are distinct than normal esophagus cells, as well as cells from duodenum and gastric tissues (Figure 2A). While a large fraction of duodenum cells expresses ACE2 (21), only $11 \%$ of the single cells from Barrett's samples have ACE2 expression above 0 (Figure 2B). However, among the cells expressing ACE2, higher levels of the gene were found in gastric, Barrett's, and duodenum cells when compared to esophagus cells (Figure 2C). Using GSEA, we found that genes associated with regulation of cellular $\mathrm{pH}$ were enriched among the up-regulated genes in gastric, Barrett's and duodenum cells when compared to esophagus cells (Figure 2D). 
medRxiv preprint doi: https://doi.org/10.1101/2020.09.10.20179135; this version posted September 11, 2020. The copyright holder for this preprint (which was not certified by peer review) is the author/funder, who has granted medRxiv a license to display the preprint in It is made available under a CC-BY-NC-ND 4.0 International license .

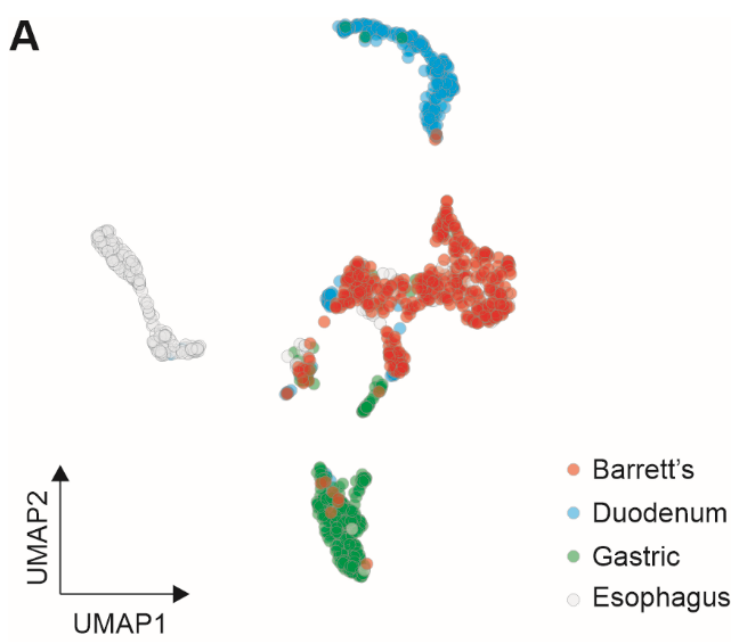

B

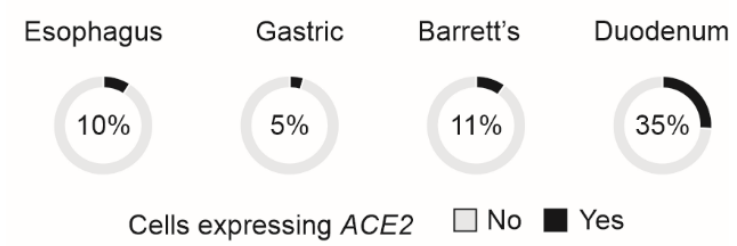

C Gastric*

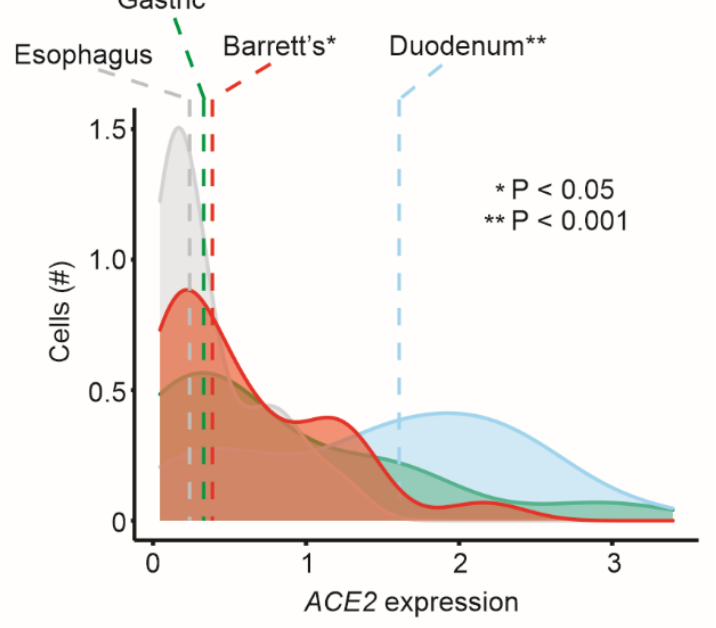

D regulation of cellular $\mathrm{pH}(\mathrm{GO}: 0030641)$

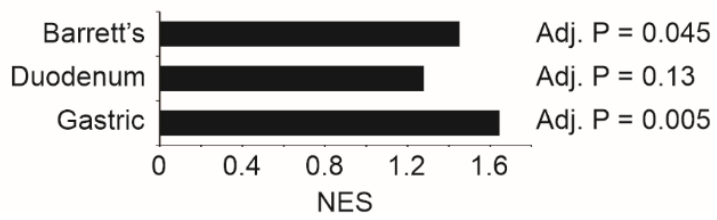

Figure 2. Single cell transcriptomics of Barrett's esophagus. A. Dimension reduction of single cells using Uniform Manifold Approximation and Projection (UMAP). Cells from 4 patients with Barrett's esophagus $(n=1,168)$ are shown. The colors represent the tissue types. B. ACE2 expression by tissue type. The pie charts show the number of single cells with (black) or without (grey) ACE2 expression (expression values $>0$ ). The fractions of 
medRxiv preprint doi: https://doi.org/10.1101/2020.09.10.20179135; this version posted September 11, 2020. The copyright holder for this preprint (which was not certified by peer review) is the author/funder, who has granted medRxiv a license to display the preprint in It is made available under a CC-BY-NC-ND 4.0 International license.

ACE2-expressing cells are indicated. C. Distribution of ACE2 expression by cells from different tissue types. The colors of histograms represent the tissue types. The dashed vertical line shows the median values of each tissue type. Student's t-test P-value between tissue types versus esophagus is indicated. D. Gene Set Enrichment Analysis (GSEA) of the 3 tissue types compared to esophagus using the regulation of cellular $\mathrm{pH}$ gene set. The normalized enrichment score (NES) are shown in the x-axis for each one of the tissue types. The adjusted $\mathrm{P}$-value of the enrichment is displayed right next to the corresponding bar.

To further evaluate whether $\mathrm{pH}$ may influence the expression of $A C E 2$, we analyzed publicly available transcriptomic studies of cells under experimentally-induced acidosis. Cells cultured at lower $\mathrm{pH}$ displayed higher expression levels of ACE2 when compared to those cultured under higher $\mathrm{pH}$ (Figure $3 \mathrm{~A}$ and $\mathrm{B}$ ). We validated this finding with human primary monocytes cultured at $\mathrm{pH}$ 7.4, 6.5 and 6.0 under normoxia. ACE2 expression was significantly increased at $\mathrm{pH} 6.5$ and 6.0 compared to $\mathrm{pH} 7.4$ (Figure 3C). The reduction of $\mathrm{pH}$ alone also significantly increased SARS-CoV-2 infection of human monocytes (Figure 3D), indicating that $\mathrm{pH}$ plays a role in ACE2-mediated SARS-CoV-2 infection.

A

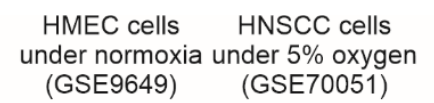

B

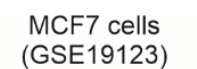

C

Human monocytes

under normoxia

$P=0.047$
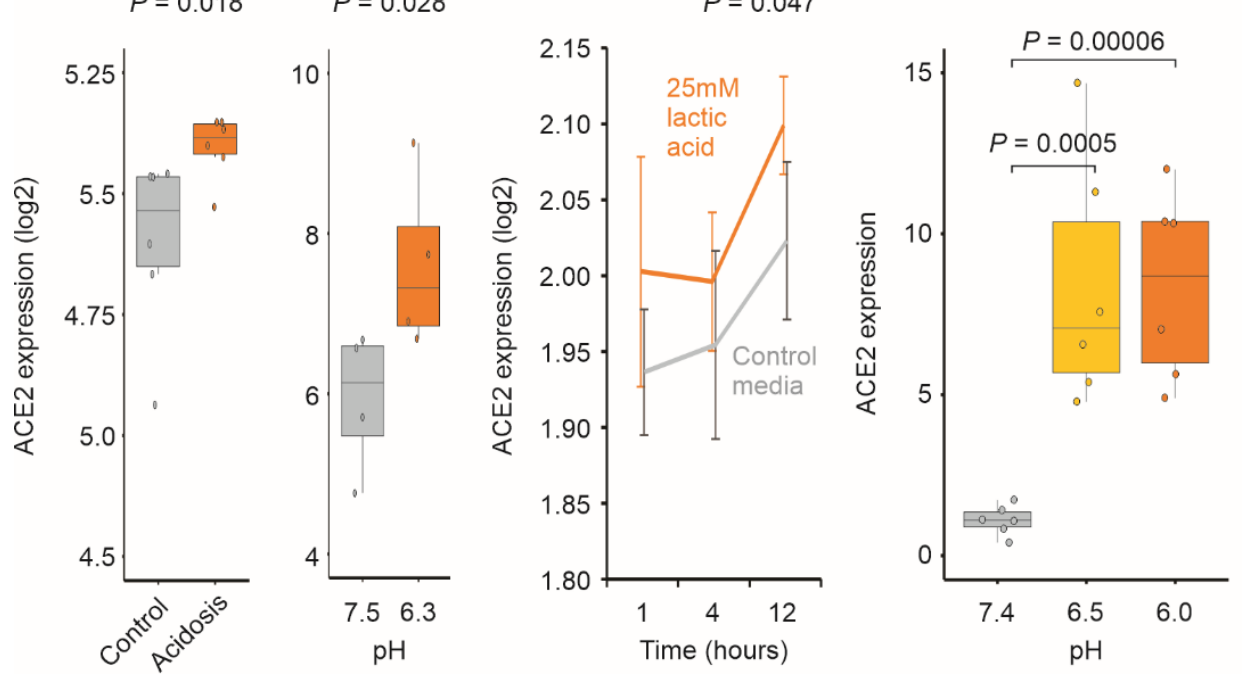

D Human monocytes

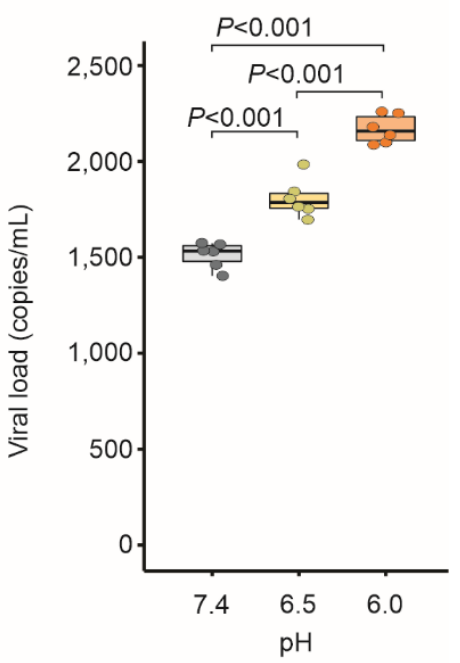

Figure 3. Acidosis increases ACE2 expression and SARS-CoV-2 infection. A. Human cells exposed to acidosis. Each boxplot represents the log2 expression of samples untreated (grey) or treated with lactic acidosis (brown) for two microarray studies (GSE9649 and GSE70051). Student's t-test P-values are indicated. B. MCF7 cells exposed to pH reduction increases ACE2 expression. Grey and brown lines represent, respectively cells treated with 
medRxiv preprint doi: https://doi.org/10.1101/2020.09.10.20179135; this version posted September 11, 2020. The copyright holder for this preprint (which was not certified by peer review) is the author/funder, who has granted medRxiv a license to display the preprint in It is made available under a CC-BY-NC-ND 4.0 International license .

control media or with $25 \mathrm{mM}$ lactic acid for 1, 4, and 12 hours (x-axis). Each point represents the mean log2 expression and the error bars the standard deviation of biological replicates. C. Acid $\mathrm{pH}$ increases ACE2 expression in monocytes. Human peripheral blood monocytes were incubated in medium at 3 different $\mathrm{pH}(6,6.5,7.4)$ for $24 \mathrm{~h}$. Each boxplot represents the fold change ACE2 expression. D. Acid $\mathrm{pH}$ increases SARS-CoV-2 viral load. Human peripheral blood monocytes were incubated in medium at 3 different $\mathrm{pH}(6,6.5,7.4)$ for $24 \mathrm{~h}$. The cells were infected with CoV-2 (MOI 0.1) for $1 \mathrm{~h}$ under continuous agitation. The RNA viral load was measured by qPCR.

Proton pump inhibitors (PPI) decrease the amount of acid produced in the stomach and are often utilized to treat subjects with GERD symptoms or with certain stomach and esophagus problems (22). The use of PPIs prior to COVID-19 may serve as a proxy for identifying subjects with tissue irritation and inflammation caused by stomach acid. In two independent cohorts of 551 and 806 RT-qPCR confirmed COVID-19 patients from North and Southeast regions of Brazil, respectively, we investigated the effects of gastrointestinal discomfort and COVID-19 severity. Survival curve analysis showed that people using PPIs had a 2- to 3-fold higher risk of death compared to those not using the drug (Figure 4A). When controlling for potential confounders (i.e. age above 60 years old, diabetes, and hypertension), the adjusted hazard ratio was $2.183(95 \mathrm{Cl}: 1.635-2.914 ; \mathrm{P}<0.0001)$ for the North region cohort and 2.332 (95Cl: 1.661 - 3.274; $\mathrm{P}<0.0001)$ for the Southeast cohort (Figure 4B). These clinical findings indicate that the reduction of physiological $\mathrm{pH}$ (caused by stomach acid) may play a significant role in SARS-CoV-2 infection and COVID-19 severity. 
medRxiv preprint doi: https://doi.org/10.1101/2020.09.10.20179135; this version posted September $11,2020$. The copyright holder for this preprint (which was not certified by peer review) is the author/funder, who has granted medRxiv a license to display the preprint in It is made available under a CC-BY-NC-ND 4.0 International license .

A

North region cohort

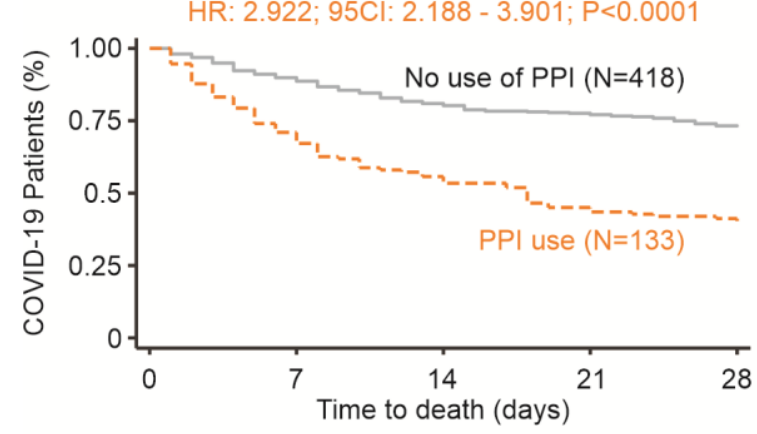

Southeast region cohort

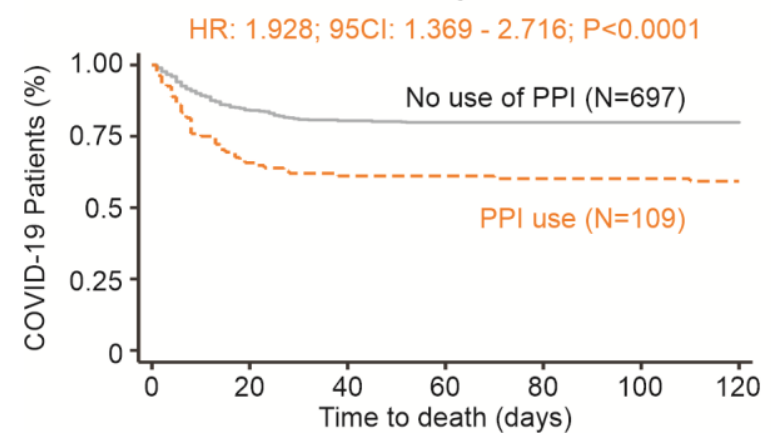

B

North region cohort

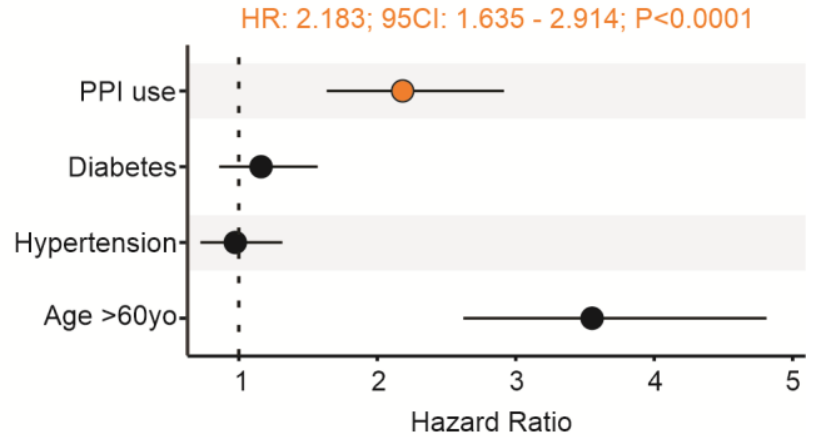

Southeast region cohort HR: 2.332; $95 \mathrm{Cl}: 1.661-3.274 ; \mathrm{P}<0.0001$

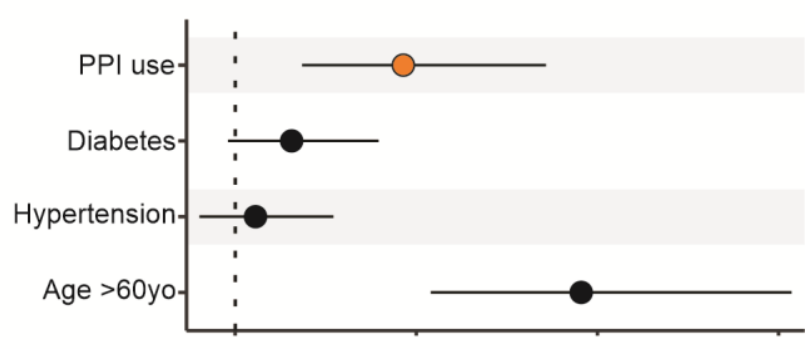

Figure 4. Increase risk of death in individuals with COVID-19 using proton pump inhibitors prior infection. A. Time to death. Kaplan-Meier survival curves showing a higher risk of death for the group of patients that used PPIs (brown) prior to admittance when compared to those not using them (grey). The North region cohort result is shown at the top and Southeast region cohort result is shown at the bottom. B. Risk of death. The forest plot presents the hazard ratios and respective $95 \mathrm{Cl}$ for the main explanatory variable (brown), as well as the potential confounders (black) used in the multivariate model. The North region cohort result is shown at the top and Southeast region cohort result is shown at the bottom.

\section{Discussion}

Our findings suggest that acid $\mathrm{pH}$ increases SARS-CoV-2 infection by up-regulating the ACE2 receptor, and this may have clinical implications for patients with GERD or Barrett's esophagus. No clear mechanism exists linking alterations in $\mathrm{pH}$ and $A C E 2$ expression. Although evidence indicates that hypoxic conditions can increase the expression of ACE2 (8, 9), the expression of neither SIRT1 nor HIF1A seem to be associated with Barrett's esophagus (Table S2). We found that known regulators of ACE2 - HNF1B (23) and FOXA2 (24) - were up-regulated in 6 out of 8 Barrett's esophagus transcriptomic studies (Table S2), suggesting that they may be involved with the pH-induced ACE2 expression in Barrett's esophagus. 
medRxiv preprint doi: https://doi.org/10.1101/2020.09.10.20179135; this version posted September 11, 2020. The copyright holder for this preprint (which was not certified by peer review) is the author/funder, who has granted medRxiv a license to display the preprint in It is made available under a CC-BY-NC-ND 4.0 International license.

Pulmonary damage, one of the main features of severe COVID-19, may lead to acute hypoxia and further respiratory acidosis. It is possible that the acidosis in the blood of some patients with severe COVID-19 (25) worsen the disease by increasing the levels of ACE2 and facilitating the entry of SARS-CoV-2 into human cells. Hypoxia itself may contribute to the regulation of $\operatorname{ACE} 2(9,26)$. In addition, elevated levels of the enzyme lactate dehydrogenase (which converts lactate from pyruvate) has been associated with worse outcomes in patients with COVID-19 (27). The excess of lactate may directly alter the extracellular and intracellular $\mathrm{pH}$ which in turn can impact ACE2 expression. The extent to which acute systemic acidosis contributes to COVID-19 severity is poorly known and deserves further research.

The drug famotidine suppresses gastric acid production by blocking the histamine 2 receptor in the stomach. Recently, Freedberg et al (28) have shown that early treatment of patients tested positive for SARS-CoV-2 significantly improved clinical outcomes among the hospitalized patients. Although the authors hypothesized that famotidine may have antiviral effects, it is possible that $\mathrm{pH}$ itself can play an important role in regulating ACE2 expression and limiting SARS-CoV-2 infection in patients.

We showed here that the previous use of PPIs is associated with unfavorable outcomes, such as the time of hospitalization, ICU admittance, and death. To the best of our knowledge, none of these associations were previously reported. Almario et al. (29) recently described that individuals using PPIs had higher chances for testing positive for COVID-19 when compared to those not using PPIs. Their hypothesis is that PPIs might increase the risk for COVID-19 by undermining the gastric barrier to SARS-CoV-2 and reducing the microbial diversity in the gut (29). Rather, we believe that PPIs are important markers of hidden comorbidities that involve the damage caused by the excess stomach acid in GI tissues.

By going from disease (Barrett's esophagus) to molecule (ACE2) to cells (in vitro experiments) and back to clinical findings (COVID-19 patients), we showed that $\mathrm{pH}$ may have a great influence on SARS-CoV-2 infection and COVID-19 severity. Additional studies should be performed to not only confirm the clinical findings on a larger scale but also to assess the molecular mechanism related to $\mathrm{pH}$-induced ACE2 expression. 
medRxiv preprint doi: https://doi.org/10.1101/2020.09.10.20179135; this version posted September $11,2020$. The copyright holder for this preprint (which was not certified by peer review) is the author/funder, who has granted medRxiv a license to display the preprint in

It is made available under a CC-BY-NC-ND 4.0 International license .

\section{References}

1. R. Tariq et al., Prevalence and Mortality of COVID-19 Patients With Gastrointestinal Symptoms: A Systematic Review and Meta-analysis. Mayo Clin Proc 95, 1632-1648 (2020).

2. L. Zhang et al., Diarrhea and altered inflammatory cytokine pattern in severe coronavirus disease 2019: Impact on disease course and in-hospital mortality. J Gastroenterol Hepatol, (2020).

3. K. S. Cheung et al., Gastrointestinal Manifestations of SARS-CoV-2 Infection and Virus Load in Fecal Samples From a Hong Kong Cohort: Systematic Review and Meta-analysis. Gastroenterology 159, 81-95 (2020).

4. A. R. Bourgonje et al., Angiotensin-converting enzyme 2 (ACE2), SARS-CoV-2 and the pathophysiology of coronavirus disease 2019 (COVID-19). J Pathol, (2020).

5. X. Zou et al., Single-cell RNA-seq data analysis on the receptor ACE2 expression reveals the potential risk of different human organs vulnerable to 2019-nCoV infection. Front Med 14, 185-192 (2020).

6. L. Lin et al., Gastrointestinal symptoms of 95 cases with SARS-CoV-2 infection. Gut 69, 997-1001 (2020).

7. B. G. G. Pinto et al., ACE2 Expression Is Increased in the Lungs of Patients With Comorbidities Associated With Severe COVID-19. J Infect Dis 222, 556-563 (2020).

8. N. E. Clarke, N. D. Belyaev, D. W. Lambert, A. J. Turner, Epigenetic regulation of angiotensinconverting enzyme 2 (ACE2) by SIRT1 under conditions of cell energy stress. Clin Sci (Lond) 126, 507-516 (2014).

9. A. C. Codo et al., Elevated Glucose Levels Favor SARS-CoV-2 Infection and Monocyte Response through a HIF-1a/Glycolysis-Dependent Axis. Cell Metab, (2020).

10. $\quad$ S. J. Spechler, R. F. Souza, Barrett's esophagus. N Engl J Med 371, 836-845 (2014).

11. S. Davis, P. S. Meltzer, GEOquery: a bridge between the Gene Expression Omnibus (GEO) and BioConductor. Bioinformatics 23, 1846-1847 (2007).

12. M. E. Ritchie et al., limma powers differential expression analyses for RNA-sequencing and microarray studies. Nucleic Acids Res 43, e47 (2015).

13. C. Prada, D. Lima, H. I. Nakaya. (Bioconductor, 2019).

14. E. Y. Chen et al., Enrichr: interactive and collaborative HTML5 gene list enrichment analysis tool. BMC Bioinformatics 14, 128 (2013).

15. A. Alexeyenko et al., Network enrichment analysis: extension of gene-set enrichment analysis to gene networks. BMC Bioinformatics 13, 226 (2012).

16. R. P. Owen et al., Single cell RNA-seq reveals profound transcriptional similarity between Barrett's oesophagus and oesophageal submucosal glands. Nat Commun 9, 4261 (2018).

17. T. Stuart et al., Comprehensive Integration of Single-Cell Data. Cell 177, 1888-1902.e1821 (2019).

18. V. Y. Kiselev et al., SC3: consensus clustering of single-cell RNA-seq data. Nat Methods 14, 483-486 (2017).

19. D. T. Severson, R. P. Owen, M. J. White, X. Lu, B. Schuster-Böckler, BEARscc determines robustness of single-cell clusters using simulated technical replicates. Nat Commun 9, 1187 (2018).

20. J. Won et al., Development of a Laboratory-safe and Low-cost Detection Protocol for SARS-CoV-2 of the Coronavirus Disease 2019 (COVID-19). Exp Neurobiol 29, 107-119 (2020).

21. M. Y. Li, L. Li, Y. Zhang, X. S. Wang, Expression of the SARS-CoV-2 cell receptor gene ACE2 in a wide variety of human tissues. Infect Dis Poverty 9, 45 (2020).

22. D. E. Freedberg, B. Lebwohl, J. A. Abrams, The impact of proton pump inhibitors on the human gastrointestinal microbiome. Clin Lab Med 34, 771-785 (2014).

23. S. Senkel, B. Lucas, L. Klein-Hitpass, G. U. Ryffel, Identification of target genes of the transcription factor HNF1beta and HNF1alpha in a human embryonic kidney cell line. Biochim Biophys Acta 1731, 179-190 (2005).

24. K. B. Pedersen, H. Chodavarapu, E. Lazartigues, Forkhead Box Transcription Factors of the FOXA Class Are Required for Basal Transcription of Angiotensin-Converting Enzyme 2. J Endocr Soc 1, 370-384 (2017).

25. T. Chen et al., Clinical characteristics of 113 deceased patients with coronavirus disease 2019: retrospective study. BMJ 368, m1091 (2020).

26. R. Zhang et al., Role of HIF-1alpha in the regulation ACE and ACE2 expression in hypoxic human pulmonary artery smooth muscle cells. Am J Physiol Lung Cell Mol Physiol 297, L631-640 (2009).

27. B. M. Henry et al., Lactate dehydrogenase levels predict coronavirus disease 2019 (COVID-19) severity and mortality: A pooled analysis. Am J Emerg Med 38, 1722-1726 (2020).

28. D. E. Freedberg et al., Famotidine Use is Associated with Improved Clinical Outcomes in Hospitalized COVID-19 Patients: A Propensity Score Matched Retrospective Cohort Study. Gastroenterology, (2020). 
medRxiv preprint doi: https://doi.org/10.1101/2020.09.10.20179135; this version posted September 11, 2020. The copyright holder for this preprint (which was not certified by peer review) is the author/funder, who has granted medRxiv a license to display the preprint in It is made available under a CC-BY-NC-ND 4.0 International license .

29. C. V. Almario, W. D. Chey, B. M. R. Spiegel, Increased Risk of COVID-19 Among Users of Proton Pump Inhibitors. American Journal of Gastroenterology NA, NA (2020).

\section{Funding:}

This work was supported by Brazilian National Council for Scientific and Technological Development (grant number 313662/2017-7); the São Paulo Research Foundation (grant numbers 2018/14933-2; 2018/21934-5; 2017/27131-9; 2013/08216-2; 2020/04836-0); and CAPES.

\section{Author declaration}

Authors declare no competing interests.

\section{Author contributions}

L.J., A.E.R.O., L.K.K.F., H.I.N. performed the transcriptome analyses. A.C.C., G.G.D., L.B.M., J.V.V, G.F.S., S.P.M., J.L.P., P.M.M. performed the experimental work. V.S.S., M.G.S.B., N.Z., F.A.G., M.L.N., F.A.V., G.C.M., W.M.M., M.V.G.L. performed the clinical analysis. H.I.N. coordinated the study. L.J. and H.I.N. wrote the manuscript with inputs from all of the co-authors.

\section{Supplementary Materials:}

Tables S1 and S2 